\title{
Morro Santana: Impactos da Urbanização
}

\author{
Autora: Alexsandra Moresco de Moura \\ Orientadora: Prof $f^{t}$ Dr $r^{a}$. Maira Suertegaray Rossato
}

Resumo: Este trabalho está embasado nos elementos que degradam a paisagem do morro Santana, como o desmatamento e a retirada de vegetação para urbanização principalmente. O morro Santana localiza-se nos municípios de Porto Alegre e Viamão. À UFRGS pertencem cerca de 600 hectares, sendo 332 hectares sugeridos para a futura Unidade de Conservação. Meu objetivo é analisar a evolução da paisagem entre 1973 e 2009 a partir de interpretação de fotografias aéreas e imagens de satélite, mapeando a expansão das áreas urbanas e redução das áreas de mata e de campo. Com isto, quero conscientizar a população da importância da preservação de um dos últimos remanescentes naturais de Porto Alegre e mostrá-las a importância do meio ambiente nas suas vidas. Infelizmente a urbanização da região metropolitana de Porto Alegre vem aumentando e, consequentemente, atos irresponsáveis da população em relação a seu habitat ocasionam prejuízos aos ecossistemas. Para analisar o desmatamento das áreas de mata e campo em comparação com o crescimento das áreas urbanas, fiz a análise de fotografias aéreas da área de 1973 e de imagens do Google Earth de 2002 e de 2009, delimitando as áreas de vegetação e áreas urbanas para posteriormente compará-las. Por meio de comparações de fotos e imagens, pude observar que houve a expansão da área urbana, isto é, teve um grande aumento de moradias em volta do morro. As áreas urbanas invadiram as áreas no morro Santana que deveriam estar repletas de vegetação. As consequências das ocupações desordenadas, por vezes irregulares, acabam ocasionando muitos acidentes bem como, erosão, deslizamento de terra, entre outros. A urbanização também altera as características de umidade e de temperatura, o que se reflete no conforto térmico.

Palavras-chave: Conforto Térmico; Desmatamento; Meio Ambiente; Morro Santana; Urbanização. 